\title{
Tax system of consolidated taxpayers groups in Russia and ways of its improvement
}

\author{
Jamila Leontieva ${ }^{1, *}$ Guzalia Klychova ${ }^{2,3}$,Evgenia Zaugarova ${ }^{1}$, Alsou Zakirova $^{2}$ and Aigul \\ Klychova $^{2}$ \\ ${ }^{1}$ Saint Petersburg State University of Economics, Department of Accounting and Audit, 191023 Saint \\ Petersburg, Russia \\ ${ }^{2}$ Kazan State Agrarian University, Department of Accounting and Audit, 420015 Kazan, Russia \\ ${ }^{3}$ Kazan Federal University, Department of Financial Accounting, 420008 Kazan, Russia
}

\begin{abstract}
One of perspective directions of business development is creation of large companies (holdings, concerns, corporations, etc.) that unite legally separate economic entities linked by organizational, economic and civil-law subordination. Increasing the efficiency of such companies and, on this basis, the growth of the national economy and its competitiveness in the world market is influenced by tax system of a group of interconnected companies. International experience has shown that these tax systems in different countries were created under the influence of a combination of various factors, most of which were due to both, historical development and mutual influence. The article presents the development of methodological approach to the improvement of Russian tax system for consolidated groups of taxpayers, which requires the integration of a number of scientific ideas and hypotheses of various schools and international experience in formation and development of the institution of consolidated tax reporting. This approach is based on the fact that consolidated group of taxpayers should be considered as an economic entity, which is a separate object of financial accounting and tax system. In present work with the help of such general scientific methods as system approach, comparison, method of data systematization and generalization, the conditions for creating consolidated group of taxpayers were studied; mechanism of consolidation and system of consolidated profitability reporting for the group of companies, their main content; the procedure for granting the right to set off losses, including losses incurred for the period preceding the year of consolidation of one company member of the group, against the profits of other members of the group.
\end{abstract}

\section{Introduction}

The process of globalization of economic relations in the world economy, characterized by a high degree of competition between economic entities, is accompanied by expansion of borders and intensification of activity on the world market of large companies (holdings,

\footnotetext{
*Corresponding author: kgaukgs@mail.ru
} 
corporations, etc.), representing vertically integrated organizational structures (VIOS) composed of legally separate economic entities.

A complex system of legal, organizational and economic relationships is formed between the organizations within such VIOS, strategically linked by a single goal.

Such large companies, harmonizing interests and combining resource potential of all VIOS participants, form integrated business alliances, connected by economic subordination relations. High level of the system of intranet self-organization in VIOS system and coordination of activities of its subjects allows such companies to be responsive to the needs of the domestic and foreign markets, to increase the efficiency of their activities, providing positive impact on the pace of development of national economic systems and growth of their competitiveness in the world market.

At the same time, the activity of VIOS affects the interests of the state, providing lion's share of the state budget revenues through tax revenues. The fact is that VIOS concentrates significant amounts of financial resources, the use of which by organizations, that build up its structure, is significantly simplified and cheaper. The creation of artificial losses by a group of companies and, thereby, reduction of its tax liabilities can cause significant damage to the state. Significant tax risks for the state can be caused by the aggressive tax system of VIOS organizations.

In this connection, the tax system is of fundamental importance in improving the effectiveness of VIOS activities, its individual organizations and national economy.

In order to create favorable conditions for business development in large companies and on this basis to ensure stability and economic growth in different countries and in different years, various concepts for formation of consolidated groups of taxpayers and consolidated financial statements have been developed.

In Russia, the system of consolidated taxation of groups of companies was introduced by the Federal Law No.321-FZ of November 16, 2011 "On Amendments to Part One and Two of the Tax Code of the Russian Federation in Connection with Establishment of Consolidated Group of Taxpayers."

Based on results of the study of international experience of applying consolidated tax reporting and conclusions of foreign and Russian scientists and practitioners, it can be argued that the main task of the legislator when introducing the system of consolidated taxation of a group of companies is to achieve a balance of business and state interests.

However, until now the Russian tax legislation does not contain corresponding regulation of the consolidated group of taxpayers and needs to be improved.

\section{Materials and Methods}

In Russia, the system of taxation of consolidated groups of taxpayers was introduced by Federal Law No.321-FZ of November 16, 2011 "On Amendments to Part One and Two of the Tax Code of the Russian Federation in Connection with Establishment of Consolidated Group of Taxpayers."

The main content of this system and possible ways to improve it, are proposed to consider in accordance with the following fundamentally important aspects of consolidated taxation:

1. Conditions for creating consolidated group of taxpayers;

2. Tax consolidation mechanism and consolidated tax reporting on profits of a group of companies, their main content;

3. Procedure for granting the right to set off losses, including losses incurred for the period preceding the year of tax consolidation, of one company group member, against net profits of the other group members; 
Possibility to recalculate tax liabilities for past tax periods when the composition of the persons forming the consolidated taxpayer is changed.

The key principle for creation of a consolidated group of taxpayers is the right of its participants to choose tax obligations on a voluntary basis.

Mandatory provision of consolidated tax reporting was applied at the beginning of the last century only in Spain and the USA, as there was a progressive tax rate on corporate profits in these countries at that time. The current system of providing consolidated tax reporting in these countries differs significantly from the previous approaches: firstly, consolidation is chosen by groups of companies voluntarily, and secondly, it allows to distribute losses between companies and deferment of tax payments.

In accordance with Art. 25.1 (par. 1) of the Tax Code of the Russian Federation: "Consolidated taxpayers group is a voluntary association of taxpayers of corporate income tax on the basis of agreement on the establishment of consolidated group of taxpayers in accordance with the procedure and on terms provided for by this Code for the purposes of calculating and paying corporate income tax, taking into account the cumulative financial result of economic activity of these taxpayers" (hereinafter referred to as CTG).

The system of consolidated taxation of most countries is characterized by the following features:

- association of CTG members on a voluntary basis;

- consolidation of group members on the basis of CTG Treaty;

- voluntary choice by group members of responsible participant;

- members of the group are taxpayers of income tax;

- calculation and payment of income tax by organizations is carried out taking into account the cumulative financial result of economic activities of group members;

- VAT accrual and its payment is not a subject to CTG.

According to international experience, the need for a system of consolidated taxation in different countries is closely related to activities of large and the largest taxpayers (holdings, corporations, concerns, etc.)

In Russia, the emergence and development of such large and the largest companies is associated with transition of Russian economy to market relations and globalization of economic relations in the world economy.

Each of these companies is a group of interconnected companies (hereinafter referred to as GIC).

GIC are economically integrated companies in which each of its members, having legal independence, carries out its entrepreneurial activities on the basis of economic interdependence and control with other members of the group. Such large companies, in comparison with legally separate enterprises, have a number of generally recognized advantages. In general, they can be defined as the ability of these groups to increase the competitive advantage and efficiency of both, group members and national economies. In this regard, the establishment of GIC in Russia is an objective and inevitable process. However, the successful functioning of Russian GIC is closely connected with the elimination of negative factors that impede the achievement of their strategic goals. Such factors, in particular, should include organizational and legal uncertainty of GIC activity. During the comparative analysis of concepts (group, holding companies and their subsidiaries, unions, associations, etc.), regulated by Russian legislation, and used in theory and practice with reference to the definition of GIC, the following main conclusions were made:

1. Groups are created by legal entities on a voluntary basis;

2. In the group, one of the legal entities is recognized as the main, parent or maternal organization, and the remaining legal entities are participants or subsidiaries; 
3. Groups are formed according to the principle of control or significant influence of one organization (main, parent or maternal) over other legal entities (participants or subsidiaries of the group). It should be noted that Russian legislation lacks a single indicator that determines whether there is control or significant influence of one organization over others. For these purposes, different indicators are set by law, depending on the type of group:

- when forming banking group, banking holding, determining its parent organization and drawing up its reporting, the indicator is used in accordance with IFRS;

- for consolidated taxpayers groups, this indicator is the share of direct and (or) indirect participation of the main organization in statutory (contributed) capital of other organizations (members), equal to not less than 90 percent;

- for groups forming consolidated financial statements such key indicator is the share of the parent organization owned by a member of GIC, determined in accordance with IFRS.

It should be noted that in international financial reporting standards (IFRS) the concept of control is not regulated by the threshold of the ownership share;

5. According to the current Russian legislation, GIC may include:

- banking groups: Russian and foreign legal entities;

- groups (CTG), formed for the purpose of calculating and taxing profits: Russian legal entities;

- groups composing the consolidated financial statements (CFS): Russian and (or) foreign legal entities;

Consequently, GICs, uniting in CTG and in groups that make up CFS, may differ (on the basis of: residence of the members in the group, control indicator), and coincide.

It should be noted that in international theory and practice of taxation, members of a consolidated group of taxpayers are usually divided into the parent companies and subsidiaries $[1,2]$.

An important aspect of tax consolidation is the conditions for taxpayers applying for participation in CIG. In accordance with Art. 25.1 par. 5 of the Tax Code of the Russian Federation, a consolidated group of taxpayers can be established if, on the date of signing the agreement on establishment of the specified group, all the following conditions are fulfilled simultaneously for all of the organizations participating in this group:

1) the total amount of federal taxes and charges, reflected in tax declarations (calculation of fees) submitted to the tax authorities for the calendar year preceding the year in which the consolidated group of taxpayers is established is not less than 10 billion rubles;

2) the total amount of proceeds from the sale of goods, products, works and services, as well as other revenues, according to the accounting records for the calendar year preceding the calendar year in which the consolidated group of taxpayers is established is not less than 100 billion rubles;

3) the total value of assets according to the accounting data on December 31 of the calendar year preceding the year in which the consolidated group of taxpayers is established is not less than 300 billion rubles.

In this regard, we consider it necessary to note that it is doubtful whether any quantitative indicators of the activities of the consolidated group of taxpayers may be established, in which the group can apply the mechanism of tax consolidation.

This principle is discriminatory and contradicts Art. 3 par. 1 of the Tax Code of the Russian Federation, which provides for universality and equality of taxation. The establishment of the right to apply consolidation depending on the absolute indicators of financial and economic activity (amount of tax obligations, amount of revenue, amount of assets) is actually supported by preferential taxation of the largest companies [3].

At the same time, most of the world's countries, including Russia, have created special simplified tax regimes, seeking to support small and medium-sized businesses. In addition, 
this approach leads to violation of the principle of market competition: the companies that dominate the industry will get even greater advantage, as competing companies that do not meet the criteria will not be able to use this mechanism $[4,5,6]$.

As the analysis of international practice shows, in order to determine the list of companies that can become members of a consolidated tax group, there is a requirement for equity participation in tax systems of foreign countries. The limits of this criterion for countries range from 50\% (Germany) to $100 \%$ (Australia, Denmark, New Zealand, Japan), with both, direct and indirect ownership taken into account.

In accordance with Art. 25.2 par. 2 of the Tax Code of the Russian Federation, a consolidated group of taxpayers can be formed by organizations provided that one organization directly and (or) indirectly participates in statutory (contributed) capital of other organizations and the share of participation in each such organization is not less than $90 \%$.

This restriction on the share participation of the parent company in the statutory (contributed) capital of the subsidiary organization (90\%) is fairly criticized by Russian scientists and practitioners $[7,8]$.

So, T. A. Kozenkova. and Zachupeyko I.A. write: "As noted in the explanatory note to the bill, interdependent organizations are considered as a single entity (single unit), subject to a high degree of control by the management company (parent company) over the activities of subsidiaries." According to the law on limited liability companies (Art. 37 of the Federal Law No.14-FZ from February 2, 1998) and on joint-stock companies (Art. 49 of the Federal Law from December 26, 1995 No.208-FZ "On Joint Stock Companies"), control over the organization is provided by participation in authorized capital of the limited liability company in amount of more than $50 \%$, and in joint-stock company in amount of $50 \%$ plus one share.

In addition, according to Art. 105.1 of the Tax Code of the Russian Federation, interdependent entities are recognized as organizations in case one organization directly and (or) indirectly participates in activities of another organization and the share of such participation is more than $25 \%$.

Thus, the share of participation in $90 \%$ limits the possibility of consolidation"[7]. Drawing on international experience, they believe that: "... the participation threshold of up to $75 \%$ provides the parent company with the opportunity to make almost any decision regarding the subsidiary, manage financial and operating policies of the subsidiary, i.e. in fact provides the necessary degree of control by the main company of subsidiaries and dependent companies" [7]. This point of view is supported by [9].

We offer the following criteria for recognizing organizations as a consolidated group of taxpayers:

1. Under the voluntary right to choose consolidated tax reporting by the company, it is necessary to create conditions for including all organizations within the vertically integrated organizational structure in CIG. This approach reduces the company's ability to manipulate its tax obligations by incorporating only "tax-friendly" organizations. Thus, the principle "all or none" must be implemented. If the group decides to apply for a tax consolidation regime, all members of the group that meet all the eligibility requirements and other requirements must join the group that submits consolidated tax reporting. This principle is used in Spain and Japan [10].

2. The effect from introduction of the previous criterion would be minimal if the group could freely regulate the percentage of equity participation at no additional cost. For example, the principal participant (parent company) can buy more shares of a subsidiary to be included in the group. To exclude one of the participants in the group (subsidiary) from the group, for the main participant (the parent company) is enough to sell its shares to a third party. 
In order to reduce the possibility of manipulating participation in subsidiaries, we propose to establish a requirement of direct or indirect equity participation at the level of $50 \%$ plus 1 share: the sale of shares to a third party in this case may lead to loss of control over the company. In addition, the low level of participation in the capital with mandatory inclusion in the group of taxpayers allows to get as close to taxation mechanism of the group of companies as a single economic unit.

3. In our opinion, the following should be included in consolidated group of taxpayers:

- $\quad$ organizations that are residents of special economic zones (except for the main company);

- $\quad$ organizations that apply special tax regimes. Obviously, these organizations, being a part of the holding company, should not use a tax privilege for small businesses [11]. In addition, inclusion of these organizations in the group will reduce the desire to use outsourcing schemes and out-staffing for tax purposes;

- organizations that have separate units outside the territory of the Russian Federation. In this case, only the profit of these organizations should be recognized within the consolidated tax group. This approach will eliminate the possibility of creating "artificial" losses abroad, the control of which by the Russian tax authorities is extremely limited. In case of non-inclusion in the group of these organizations, risks of transfer pricing for tax purposes in the territory of Russia will be preserved. The company will profitably transfer profits to such organizations, remaining unprofitable.

The tasks facing the state in attracting foreign direct investment require the creation of favorable investment climate, including, among other things, the existence of competitive tax system. In the light of these challenges, as well as practices that will emerge after the initial stage of consolidation system, the possibility of consolidating financial results in the following options for carrying out activities through permanent missions, used in international tax practice, should be considered (Fig. 1).

\section{Results}

In the world practice there is a wide variety of consolidation models for the purposes of calculating income tax. In this case, even within one model, there are different mechanisms of consolidation. The most typical is the calculation of the corporation's profit separately at the level of each member, followed by a set of received amounts at the group level after certain adjustments. The parent company is obliged to calculate and pay the tax on behalf of the whole group. This approach is also the most common among countries that only introduce tax regimes of consolidated taxpayers into national tax systems.

In accordance with par. 5 of Art. 25.5 of the Tax Code of the Russian Federation (TC $\mathrm{RF}$ ), a member of a consolidated group of taxpayers is obliged to submit to its responsible group member calculations of the tax base for income tax in respect of its income and expenses received.

The object of taxation on profit is the amount of the total profit of consolidated taxpayers.

According to par. 5 of Art. 321.2 of the Tax Code of the Russian Federation, the consolidated tax base of consolidated group of taxpayers is defined as the arithmetic sum of the incomes of all members of this group, reduced by the arithmetic sum of expenses of all its members. 


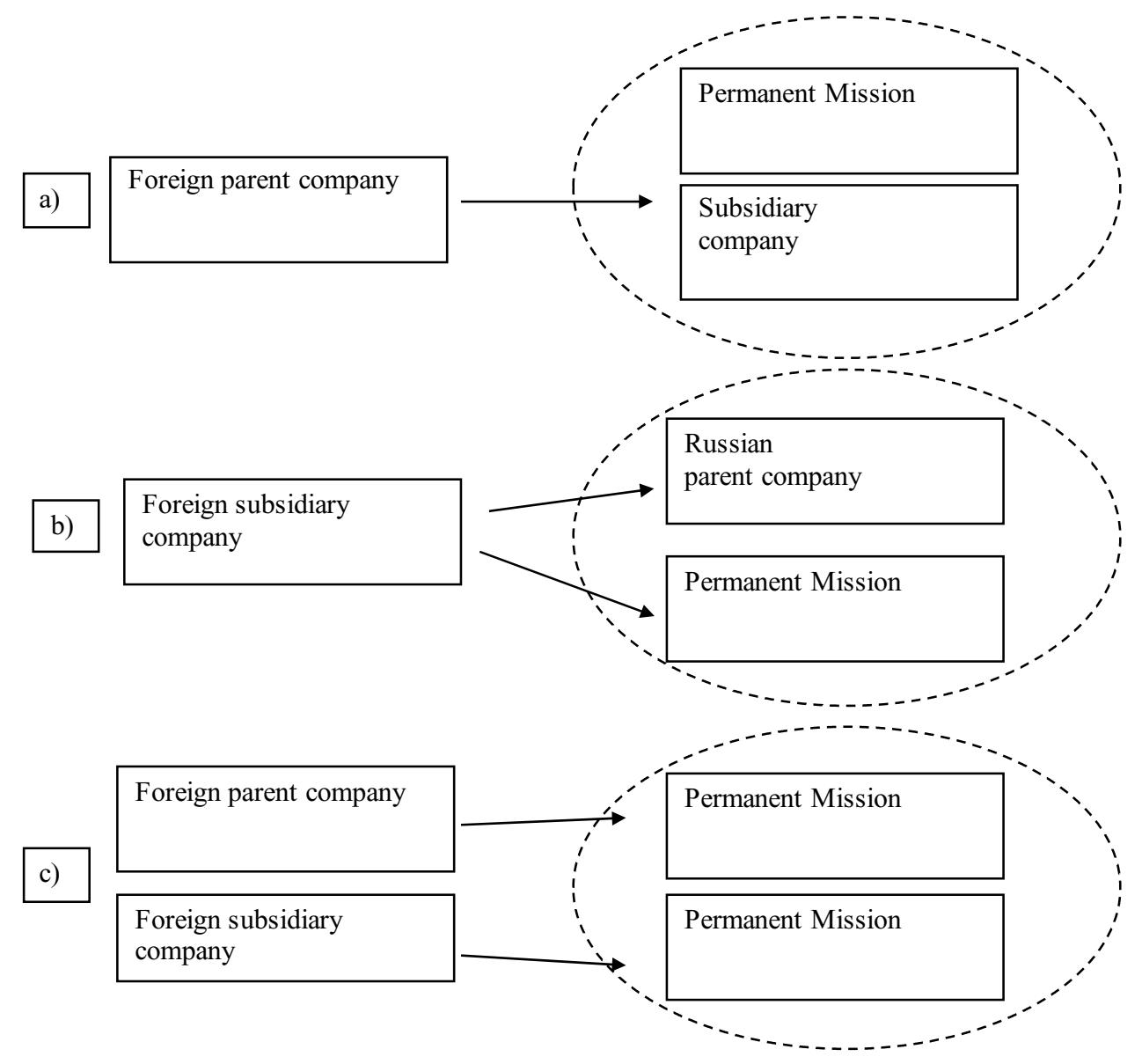

Fig. 1. Options for consolidating financial results.

At the same time, unlike the Tax Code of the Russian Federation, we consider it necessary to take into account the financial result from conducting business operations between organizations that are members of the consolidated group [12]. The point is that in terms of tax obligations, transfer pricing between the group members is meaningless: one participant generates income, the other, respectively, expenses. In addition, this approach simplifies the system of tax registration of the taxpayer and administration by the tax authorities [13].

In order to ensure the neutrality of tax consolidation mechanism, it is necessary to provide for the application of a common accounting policy for taxation purposes of corporate income tax (in respect of similar items of property and liabilities, income and expenses of members of the specified group).

The responsible participant of the consolidated group of taxpayers must submit to the tax authority a tax declaration which specifies the consolidated settlement base, as well as the tax base of each of the members of this group.

Then the responsible participant calculates and transfers to the federal budget on the results of the tax period at the place of his location the amount of advance payments, as well as income tax. The amounts of income tax (advance payments) to be credited to the budgets of the constituent entities of the Russian Federation, members of CTG and their 
separate subdivisions are calculated at the tax rates applicable in the territories where they are located.

The mechanism of distribution of tax liabilities among the participants is of fundamental importance for ensuring the balance of tax revenues for the regions in which CTG members are located. Art. 288 of the Tax Code of the Russian Federation, in our opinion, proposes an effective mechanism of distribution of tax obligations:

1. Together with the calculation of the tax base, each member of the consolidated group of taxpayers must provide the responsible member of the consolidated group of taxpayers with information on the average number of its employees (labor costs) and the residual value of its depreciable assets.

2. Further, the tax base of each member of the consolidated group of taxpayers is calculated by the responsible member of the consolidated group of taxpayers as the share of the consolidated calculation base based on the average arithmetic value of specific weight of the average number of employees (labor costs) and the specific weight of depreciated property of a particular participant in the consolidated group of taxpayers, in the average number of employees (expenditures and labor costs) and residual value of deprecating property on consolidated group of taxpayers as a whole.

This approach allows the fairest distribution of the tax base between the group members and, accordingly, the regions. The number of employees and assets used for financial and economic activities most accurately allow to distribute the base in accordance with the actual functions performed by the group member and risks.

Analysis of international experience shows that in most states that have implemented a system of consolidated taxation of groups of companies, the task to create a "fair" tax system that fits both regions and the center, has not been set. In this regard, we believe that the statement of M. Volkova, the head of corporate practice of the Law Office "Leontiev\&Partners" is fair: "The creation of consolidated tax reporting was not aimed at redistribution of tax flows between regions, it is a kind of "side effect" in respect of corporate income tax, it does not concern other types of tax" [14].

In foreign practice, the procedure for distribution of tax liabilities for income tax between members of the group is preliminary agreed upon in each company-member of the group and is reflected in the Agreement (Treaty) on the establishment of CTG.

Evaluating CTG tax system, some experts consider: "The new rules will significantly reduce the opportunities for manipulating prices and create profit centers in the "right place". It will be easier for taxpayer's groups with centralized preparation of unified reporting "[14].

M. Volkova rightly notes: "There will be an opportunity to take into account the aggregate income and expenses for all companies of the group, that is, there will be no situation when some companies show super profits and pay large taxes, while for other companies the financial result is either zero or with a minus. Consolidated groups do not need to deduce the main profit offshore (regions with the lowest tax rate), as profits and losses for all companies of the group are estimated together. Thus, the amount of taxes paid on the territory of the Russian Federation should increase "[14].

As for the indicators that serve as the basis for the distribution of tax obligations provided for by the Tax Code, we consider them to be sufficiently reasonable and consistent with the principle of fair treatment.

According to the Tax Code of the Russian Federation (Art. 105.14, par. 4.1), transactions between participants of CTG are not controlled.

In order to delay recognition of profits from the transfer of assets within the group of companies in the Tax Code of the Russian Federation, the following conditions for the accounting of assets are provided: 
1. When determining the initial value of a fixed asset, the member of consolidated group of taxpayers shall not take into account the costs of its acquisition, construction, manufacture, delivery and bringing it to the state in which it is suitable for use, incurred in acquiring fixed assets from other participants of the specified group.

2. If the participant of consolidated group transfers (free of charge) the fixed assets to another member of the group, or when the said group is liquidated (the participant leaves the said group), the original value of the fixed asset does not change.

3. Valuation of assets and liabilities in the tax accounting of organizations that are members of consolidated group of taxpayers should be taken equal to their valuation in tax accounting at the time of entry of organizations into consolidated group of taxpayers. It is this assessment of assets and liabilities that should be used to determine the tax base for corporate income tax when the asset is sold (performance of the obligation) to organizations that are not members of the consolidated taxpayers group.

4. Assets and liabilities transferred (sold) between the participants ofone consolidated group of taxpayers should be reflected in the tax accounting of the members of consolidated group on the tax accounting data of the transferring party at the time of transfer (sale).

In order to exclude the possibility of tax abuses, when it is transferred to a member of the group for a tax-free sale of an asset, and then shares of this company are sold, in our opinion, it is necessary to legislate the restriction for unreasonable application of this tax preference. The restriction must be based on the following principle: if the receiving party for one reason or another leaves the group within a certain period of time after the transfer of the asset, it is obliged to calculate the capital gains tax based on the current market value of the asset, received from the other group company at the original cost. This principle is successfully used in the UK. The period during which the asset must be held by the receiving party for the tax-free transfer of assets before the member leaves the group is 6 years.

\section{Discussion}

The key in taxation of consolidated groups of taxpayers is the presence of the following elements:

- $\quad$ possibility of mutual compensation of profits and losses of the group members;

- deferral of recognition of profits from the transfer of assets within a group of companies.

In the practice of developed countries in which the tax consolidation system operates, there are different rules for offsetting losses.

In Austria and Germany, the company's losses prior its entry into the group with the Organschaft regime can be compensated for by the profits of the company [15].

Similar rules exist also in Denmark, Italy, Luxembourg, Mexico, the Netherlands and Portugal.

In France, the leaving group is forfeited the right to deduct the amount of losses from the tax base, and its losses remain in the parent company [16]. In accordance with the rules of the Netherlands, after the dissolution of fiscal unity, the subsidiary that has withdrawn from it may postpone for the future period its own pre-consolidation losses, as well as losses of fiscal unity that can be distributed in favor of subsidiaries. In Japan, subsidiaries cannot postpone their pre-consolidation losses for future periods, but this is possible for the parent company. In New Zealand, the restrictions concern both the rules of grouping losses and the consolidation regime. In the United States, there is a mechanical rule that governs the recognition of losses received by a group member prior to consolidation, according to which the distribution of losses is permitted, provided that losses occur to the unprofitable enterprise while it is part of the consolidated group. 
The system of CTG taxation, approved by the Tax Code of the Russian Federation, provides the group members the possibility of mutual compensation of profits and losses and deferral of recognition of profits from the transfer of assets within the group.

Rules for recognition of losses have the following peculiarities established by the Tax Code of the Russian Federation (Art. 283, par. 6):

1. If CTG incurred a loss (losses) in the previous tax period or previous tax periods, the responsible member of such group has the right to reduce the consolidated tax base of the current tax period for the entire amount of the loss or for a part of this amount;

2. Member of CTG after leaving the group (termination of this group):

- $\quad$ shall not be entitled to reduce the tax base of the current tax period by the amount of loss received by the group during its validity period (for part of this amount);

- have the right to reduce the tax base of the current tax period by the amount of loss received by the said organization on the basis of tax periods (for part of this amount) in which it was not a member of CTG. At the same time, the period during which the taxpayer is entitled to carry out the transfer of loss for the future, increases by the number of years during which such taxpayer was a member of CTG;

3. If organization that is a member of CTG during its participation in this group has been reorganized in the form of a merger or acquisition, after its withdrawal from the said group (termination of this group), it has the right to reduce the tax base of the current tax period by the amount of the loss received by the organizations (for part of this amount), the assignee of which is the organization that left the group, following the tax periods in which such reorganized organizations were not participants of CTG;

4. If the organization that was a member of CTG during the period of its participation in the specified group was re-established by division of the organization, after the withdrawal of this group (termination of this group), this organization also has the right to reduce the tax base of the current tax period by the amount of the loss received by the organization (for part of this amount), the legal successor of which is the organization that left the group on the basis of tax periods in which such a reorganized organization was not a member of CTG.

At the same time, in order to improve the taxation of CTG, we consider it expedient to introduce the following rules of loss accounting for the group members:

- Current losses of group members can be fully credited against the profits of other group members;

- The amount of losses that are accepted for crediting shall be not more than $20 \%$ of the profit of the consolidated tax group in the current tax period;

- Losses not credited in the current tax period are transferred forward to the following tax periods;

- Losses of a member of a group incurred before entering a consolidated tax group may be credited only to the profit of this member of the group in accordance with the general rules of Art. 283 of the Tax Code of the Russian Federation;

- If the group member's losses incurred prior to joining the consolidated tax group were not fully credited to the profit of the member at the time of its presence in the group, the amount of this loss shall be transferred to the tax periods after the withdrawal of the taxpayer from the group.

The principal difference between the proposed procedure for offsetting losses is that, in our opinion, it is necessary to establish the maximum amount of losses credited to the profits of the consolidated tax group. The need to introduce this norm is necessitated by the need to create a restrictive framework for potential tax abuse. The proposed limit of losses qualifying in the profit of CTG should be $20 \%$. This value is below the loss transfer norm for the current tax period. Under this approach, the conditions for offsetting losses within a consolidated tax group are more favorable than when transferring losses of an 
"unconsolidated" taxpayer. The level below $20 \%$ will reduce the attractiveness of consolidated taxation system as a mechanism for taxation of a single economic entity.

If we introduce this restriction on offsetting losses, we also consider it possible to allow the transfer of losses received by the taxpayer prior to consolidation to the profit of the current tax period, except for losses incurred from transactions with other members of the group prior to consolidation.

As it was already shown above, multilevel taxation is a consequence of consideration of the consolidated tax group as a separate taxpayer. Taxation occurs both at the group level and at the shareholder level. As a result, the initial value of assets available at each level is accounted for. The responsible member (parent company) owning the shares of the member in the group (subsidiary) takes these shares into account at the initial cost. When they are realized, the company makes profit (if market price of the shares has risen relative to the original value) or a loss (if the market price of the shares has fallen relative to the original value).

The cost of shares is directly affected by the financial and economic activity of the organization. The price is determined on the basis of supply and demand, but benchmark is the price, defined as the ratio of dividends paid by the company to the rate of return of the given type of securities. In addition, the share price is affected by the potential return on investments made by the company. Obviously, the result of financial and economic activity affects both, the possibility of paying dividends and investing. If a member of the group (subsidiary) receives a loss, the loss is transferred to subsequent tax periods. In normal market conditions, this loss leads to a decrease in the value of the shares of this company. Thus, if a company that owns shares in unprofitable organization sells these shares, then there is a loss from lowering the value of investments. This loss reduces the taxable base on the investor's income tax. A loss-making company, if it gains profit in the future, will also be able to reduce this profit by the amount of loss. As a result, there is an effect of double recognition of losses.

In case of consolidated taxpayer, this approach contradicts one of the basic ideas underlying the tax consolidation system, which ignores the separate existence of subsidiaries. This idea is often called the "single organization" approach. If the group is actually to be treated as a single subject of taxation, the two above taxes are unacceptable elements of double taxation (or deduction) and should be eliminated. Indeed, if the unprofitable organization that is part of the group can immediately reduce the tax base of CTG and the shareholder owning shares of this company sells its stake at the market price, then the consolidated tax group will experience a double loss: at the level of the unprofitable organization and at shareholder level. At the same time, when making profit, the value of the company's shares raises, which is also reflected in the shareholder's potential profit.

In the United States, there are rules for adjusting the accounting value of investments, according to which the initial value of investments in a subsidiary should be governed by the following rules:

- $\quad$ taxable income (increase of initial value of investments);

- $\quad$ loss before tax (decrease in initial value of investments).

Double mechanism of losses recognition actually provided by the tax system potentially leads to manipulation of tax obligations. In this regard, it's necessary to provide within the framework of the consolidated taxation system a mechanism for adjusting the initial value of investments in a subsidiary, depending on the actual results of the company's activities:

- increase of the initial value of shares (ratio) on the amount of net profit of the company; 
- reduction of the initial value of shares (ratio) by the amount of loss of the company, adjusted to the tax rate on the income tax (at the rate of $20 \%$, the reduction of the value of investments in the subsidiary should be $80 \%$ of the amount of loss);

- reduction of the initial value of shares (ratio) by the number of dividends paid by the subsidiary.

\section{Conclusions}

Thus, our study showed that in most developed countries, holding structures using consolidation mechanism are considered as a special subject of tax relations. Consolidated group of taxpayers is not just a set of independent economic entities, but a kind of economic unity. This design is considered as a new, separate object of financial accounting and tax system. Consolidation of tax liabilities is one of the determinants of entrepreneurial unity.

The CTG system introduced in Russia in 2012 has a lot in common with foreign theory and practice of taxation of large companies. However, in our opinion, it requires changes and additions.

When developing proposals to improve the system of CTG, set out in this paper, we proceeded from the following fundamental principles:

- it is necessary to limit "aggressive tax planning" with the use of the mechanism of consolidation by taxpayers;

- it is necessary to create conditions for ensuring effective tax control by tax authorities.

The implementation of these principles will allow, in our opinion, to balance state and business interests.

\section{References}

1. H. J. Ault, Comparative Income Taxation: A Structural Income Analysis. (2007)

2. S. Plasschaert A EU Tax on Consolidated Profits of Multinational Enterprises/ European Taxation. January (2007)

3. J.G. Leontieva, E.V. Zaugarova J. of Legal and Economic Studies. 2, 109 (2014)

4. J.G. Leontieva, E.V. Zaugarova. Bulletin of East-Siberian State University of Technology and Management, 5 (50), 149 (2014).

5. G.S. Klychova, A.R. Zakirova, E.R. Kamilova International Business Management, 10, 5254 (2016).

6. G.S. Klychova, B.G. Ziganshin, A.R. Zakirova, G.R. Valieva, A.S. Klychova, Journal of Engineering and Applied Sciences, 12, 4958 (2017).

7. T.A. Kozenkova, I.A. Zachupeiko Accounting in Civil Engineering Organizations 8-9, 4 (2012)

8. N.A. Kondrashova, Taxes and Financial Law 8, 2 (2012)

9. Yu.A. Krokhina, Financial Law 4 (2013)

10. A.G. Prats, ECTR 2 (2003).

11. G.S. Klychova, E.N. Fakhretdinova, A.S. Klychova, N.V. Asian Social Science 11 11, 318 (2015)

12. J.G. Leontieva, E.V. Zaugarova Bulletin of East-Siberian State University of Technology and Management, 4 (49), 85 (2014). 
13. J.G. Leontieva, E.V. Zaugarova Bulletin of the Russian Academy of Natural Sciences (St. Petersburg), 18- 2, 37 (2014).

14. URL: www.vZ.ru/economy/2012/6/28/585935.html

15. J.G. Leontieva, E.V. Zaugarova Institute of Consolidated Taxation of Company Groups in Germany. Modern Paradigms of Scientific Views - Collected Scientific Articles by Results of the International Scientific and Practical Conf., 132 (2016).

16. J.G. Leontieva, E.V. Zaugarova Institute of Consolidated Taxation of Company Groups in France. Modern Paradigms of Scientific Views - Collected Scientific Articles By Results of the International Scientific and Practical Conf., 137 (2016). 